\title{
Original article (short paper) \\ Physical training at sub-threshold intensity reduces the prevalence of hepatic steatosis after high-fat diet in rats
}

\author{
Valdemar Guedes da Silva \\ Federal University of Mato Grosso, Cuiabá, MT, Brazil \\ Fabrício Cesar de Paula Ravagnani \\ Mato Grosso Federal Institute of Education, Science and Technology, Cuiabá, MT, Brazil \\ Allan da Mata Godois \\ Federal University of Mato Grosso, Cuiabá, MT, Brazil \\ Odashiro Maçanori \\ Federal University of Mato Grosso do Sul, Campo Grande, Brazil \\ Fabrício Azevedo Voltarelli \\ Federal University of Mato Grosso, Cuiabá, MT, Brazil \\ Celso Massaschi Inouye \\ Federal University of Mato Grosso do Sul, Campo Grande, Brazil \\ Christianne de Faria Coelho-Ravagnani \\ Federal University of Mato Grosso, Cuiabá, MT, Brazil
}

\begin{abstract}
The purpose of the present study was to evaluate the effects of swimming physical training with sub-threshold load on the prevalence of hepatic steatosis in Wistar rats fed high-fat diets (cafeteria or baru). After 2 months of cafeteria diet administration, the rats were separated into 6 groups: Sedentary or Trained Baru diet; Sedentary or Trained Cafeteria diet; Sedentary or Trained standard diet. The trained groups were subjected to swimming exercise at sub-threshold intensity ( $2 \%$ of body weight) during 8 weeks, $5 \mathrm{x} /$ week, $1 \mathrm{~h} /$ day. The body weight and hepatohistological changes were analyzed. Sedentary groups fed high-fat diets presented higher body weight gain when compared to control trained group. The swimming training at the proposed intensity was able to prevent the hepatic steatosis in rats fed high-fat diets.
\end{abstract}

Keywords: swimming exercise, sub-threshold intensity, high-fat diet, hepatic steatosis

Resumo - "Treinamento físico na intensidade sub-limiar reduz a prevalência de esteatose hepática em ratos alimentados com dietas hiperlipídicas." O objetivo do presente estudo foi avaliar os efeitos do treinamento físico de natação com carga sub-limiar sobre a prevalência de esteatose hepática em ratos Wistar alimentados com dietas hiperlipidícas (cafeteria ou baru). Após dois meses de dieta cafeteria, os ratos foram separados em 6 grupos: Baru treinado ou sedentário; Cafeteria treinado ou sedentário; Controle treinado ou sedentário. Os grupos treinados foram submetidos ao exercício de natação em intensidade sub-limiar, durante 8 semanas, $5 \mathrm{x} / \mathrm{semana}, 1 \mathrm{~h} /$ dia. As alterações de peso corporal e histopatológicas foram analisadas. Os grupos sedentários alimentados com dietas hiperlipídicas apresentaram maior ganho de peso corporal se comparados ao grupo controle treinado. O treinamento de natação na intensidade proposta diminuiu a prevalência de esteatose hepática induzida por dietas hiperlipídicas.

Palavras-chave: exercício de natação, intensidade sub-limiar, dieta hiperlipídica, esteatose hepática

Resumen - "Entrenamiento físico de intensidad sub-umbral reduce la prevalencia de esteatosis hepática en ratas alimentadas con hiperlipidemia dietas." El objetivo de este estudio fue evaluar los efectos de la natación de entrenamiento físico con la carga por debajo del umbral de la prevalencia de la esteatosis hepática en ratas alimentadas con dietas con hiperlipidemia (cafetería o baru). Después de dos meses de dieta de cafetería, las ratas se dividieron en 6 grupos: entrenados o sedentarios Baru, entrenados o Cafeteria sedentaria; Control entrenados o sedentario. Los grupos formados fueron sometidos a nadar ejercicio de intensidad por debajo del umbral durante 8 semanas, y 1 hora al día 5x/week. Se analizó el peso y la histopatología. Grupos 
sedentarios alimentados con una dieta alta en grasas aumentó más de peso en comparación con el grupo de control entrenado. El entrenamiento de natación disminuyó la prevalencia de la esteatosis hepática inducida por la dieta alta en grasas.

Palabras claves: ejercicio, dieta rica en grasas, esteatosis hepática

\section{Introduction}

Non Alcoholic Fatty Liver Disease (NAFLD) results from abnormal lipid metabolism and generates an accumulation of triglycerides in the hepatocytes (Jou, Choi, \& Diehl, 2008). NAFLD may be considered a mild manifestation of liver disease (Jou et al., 2008; Lewis \& Mohanty, 2010) and serves as prognosis for more severe forms of liver involvement, such as nonalcoholic steatohepatitis (NASH) (Krawczyk, Bonfrate, \& Portincasa, 2010). This pathology has been considered the main factor responsible for hepatic changes in Western countries (Cotrim et al., 2011; Krawczyk et al., 2010), and is still a clinical aspect observed in a large portion of Brazilian patients (Cotrim et al., 2011).

Therefore, NAFLD is considered an emergent pathology and its course may have significant consequences for morbidity and mortality (Lewis \& Mohanty, 2010). The prevalence of changes in hepatic functions increases in parallel with regard to both the metabolic syndrome and obesity (World Healt Organization. Joint WHO/FAO Expert Consulation, 2002). This raises discussion, considering that for some time obesity has been shown to be pandemic and a factor for the development of chronic noncommunicable diseases (World Healt Organization. Joint WHO/ FAO Expert Consulation, 2002). On the other hand, the main characteristic of the metabolic syndrome is insulin resistance which, in its broad spectrum of alterations, intensifies the accumulation of hepatic lipids (Bugianesi, McCullough, \& Marchesini, 2005).

Obesity results from energy imbalance, so that the main domains of interventions are related to the energy balance, for which the main modifiable component is physical activity (Popkin, Adair, \& Ng, 2012). Considering the intimate relations of NAFLD with overweight, obesity and metabolic complications, physical exercise plays a primordial role in its treatment(Johnson, Keating, \& George, 2012). In this context, it is known that sedentarism and/or low cardiorespiratory fitness, combined with excessive calorie intake, lead to the accumulation of fat in the liver, indicating that the majority of cases of NAFLD could be avoided by increasing the levels of physical activity (Rector \& Thyfault, 2011).

The interaction between different protocols of physical exercise and administration of diets may lead to the prevention of excessive accumulation of both body and hepatic fat (Horowitz, 2003). It has been demonstrated that physical activity attenuates the progression of NAFLD in genetically hyperphagic and obese animal models (Rector et al., 2008b), so the interruption of daily physical activity triggers a rapid systemic response, which activates specific precursors linked to hepatic steatosis, without causing changes in bodyweight, adipose mass and food intake (Rector et al., 2008a). These results have demonstrated the important role of voluntary physical activity in factors that may promote NAFLD. However, in clinical practice it is difficult to monitor this type of activity, and furthermore, the quantity necessary for developing benefits to health is not clear. Never- theless, light intensity physical training may easily be supervised and safely included in the patient's routine.

A large portion of the studies have fostered knowledge about the epidemiology, pathogenesis and treatment of NAFLD, but there are still gaps in investigations, mainly with respect to the parameters for structuring physical training. Therefore, further studies are necessary, with the purpose of improving understanding of the effects of different training intensities on the prevalence of NAFLD in view of the offer of a high-fat diet, since this type of diet may cause damage to the liver. Therefore, the aim of the present study was to evaluate the effect of swimming physical training with sub-threshold load on the prevalence of NAFLD in rats fed high-fat diets. Our initial hypothesis was that sub-threshold physical training would be effective in reducing the prevalence of hepatic steatosis in rats fed a cafeteria a high-fat diet.

\section{Methods}

\section{Animals}

The initial sample was composed by 42 male Wistar rats ( 30 days of life), obtained from Bioterium of the Federal University of Mato Grosso do Sul (UFMS). The animals were housed in collective cages ( 5 rats/cage), kept at a constant temperature of $26^{\circ} \mathrm{C}( \pm 2)$, with a $12 / 12$ hour light/dark cycle, and food and water consumption ad libitum. This study was previously approved by the Ethics Committee on the Use of Animals in Research of the Federal University of Mato Grosso do Sul (UFMS) (Protocol No. 183/2008).

\section{Experimental diet protocols}

After weaning, the animals were fed a cafeteria a high-fat diet, prepared on the basis of toasted peanuts and milk chocolate (Estadella, Oyama, Dâmaso, Ribeiro, \& Nascimento, 2004) for 8 weeks, without performing physical exercise. At the end of this period, the animals were randomly divided into six groups, according to the diet administered and either performing physical exercise, or not: Baru Trained $(n=5)$; Baru Sedentary $(n=5)$; Cafeteria Trained $(n=4)$; Cafeteria Sedentary $(n=6)$; Control Trained $(n=4)$; Control Sedentary $(n=4)$. The Cafeteria Groups continued with the same diet of the first 8 weeks, and the Baru Groups had their fractions of peanuts and chocolate replaced with Baru oil extract. The Control Group was fed a normal-fat diet (Commercial ration NUVILAB $®)$. All the formulations were in accordance with the criteria of the American Institute of Nutrition (Reeves, Nielsen, \& Fahey, 1993) and were given to the animals in the form of pellets. The composition of each diet is shown in Table 1. 
Table 1. Comparison between the compositions of the diets.

\begin{tabular}{lccc}
\hline \multirow{2}{*}{ Ingredient } & \multicolumn{3}{c}{ Diets } \\
\cline { 2 - 4 } & Cafeteria & Baru & Control \\
\hline Moisture (\%) & 5.13 & 5.87 & 12.5 \\
Ash (\%) & 1.96 & 2.69 & 10.0 \\
Fat (\%) & 21.58 & 17.34 & 4.50 \\
Protein (\%) & 16.87 & 21.08 & 22.00 \\
Carbohydrate (\%) & 38.88 & 42.95 & 59.00 \\
Fiber (\%) & 14.45 & 10.07 & 8.00 \\
Total energy (kcal/100g) & 417.22 & 412.18 & 348.5 \\
\hline
\end{tabular}

\section{Physical training protocol}

The physical training protocol consisted in swimming in a pool with lanes $(50 \mathrm{~cm}$ high by $15 \mathrm{~cm}$ in diameter) with duration of 8 weeks, 5 times/week, $1 \mathrm{~h} /$ day, and carrying out a load equivalent to $2 \%$ body weight. This load is considered sub-threshold with regard to the aerobic-anaerobic metabolic transition range of rats (Voltarelli, Gobatto, \& de Mello, 2002). In the two weeks preceding the beginning of the training protocol, the animals were adapted to the liquid environment in order to reduce the stress related to physical exercise performed in the water, without causing significant physiological adaptations (Harri \& Kuusela, 1986).

In the first week of adaptation, the animals were kept in shallow water at a temperature of $31 \pm 1^{\circ} \mathrm{C}$ during 30 minutes, with progressive daily increase in the volume of water. In the second week of adaptation, the rats carried out "backpacks" closed with Velcro ${ }^{\circledR}$ equivalent to $2 \%$ of the body weight fastened to the animal's thorax with the use of elastic, with progressive time increase $(5,15,30,45$ and 60 minutes/day). After the adaptation period, the 8 weeks of training was started. The animals were weighed on a semi-analytic scale (Marte-model AS 5.500®) to adjust the load at the beginning of each week and to calculate the delta weight, defined as the difference between the final and initial weight.

\section{Histopathological evaluation}

The animals were killed by $\mathrm{CO}_{2}$ inhalation 48 hours after the last physical training session. After this, an incision was made in the abdominal cavity on three alba line, from the pubis up to the xyphoid cartilage, to exposure the abdominal content. The livers were extracted and immersed in Bouin Fixer $(20 \mathrm{~mL}$ formol; $5 \mathrm{~mL}$ glacial acetic acid; $75 \mathrm{~mL}$ picric acid; $1.5 \mathrm{~g}$ chromic acid) for 24 hours. The samples were transferred to a $70 \%$ alcohol solution to eliminate the fixer residues, and the solution was renewed whenever necessary. After dehydration ( $70 \%$ alcohol), the samples were impregnated with liquid paraffin and sectioned in a Minot type microtome, adjusted to $5 \mu \mathrm{m}$ (micrometers). The cuts fixed on slides were stained with Hematoxylin-Eosin. The analyses were performed using a polarized light microscope with a video camera (Olympus BX-51).

The vacuoles were identified by blank spaces inside the hepatocytes and classified as absence or presence of NAFLD (moderate or severe), according to the example in Figure 1. The diagnosis was determined by a histopathologist.

\section{Statistical analysis}

The results were expressed as Mean \pm Standard Deviation (SD). One-way ANOVA followed by the Tukey post hoc tests were used to verify the difference in delta weight among the groups. The differences were considered significant when $p<.05$. The diagnosis of the histopathological analyses was presented in absolute (n) and relative (\%) values. All analyses were performed with the software program Mini$T a b$ v.16.2.2.

\section{Results}

Relative to the rats which were fed a high-fat diet, only the group "cafeteria trained" showed a significant increase of body weight. In the control groups, there was a reduction in body weight in trained rats and an increase in sedentary animals, but the difference was not statistically significant. The variation in body weight among the groups was significant only when the sedentary group, which was fed a high-fat diet, was compared to the control trained group (Table 2).

The association between high-fat diets and sedentarism significantly increased the delta weight $(\Delta=$ final weight initial weight) in comparison with the trained control group.
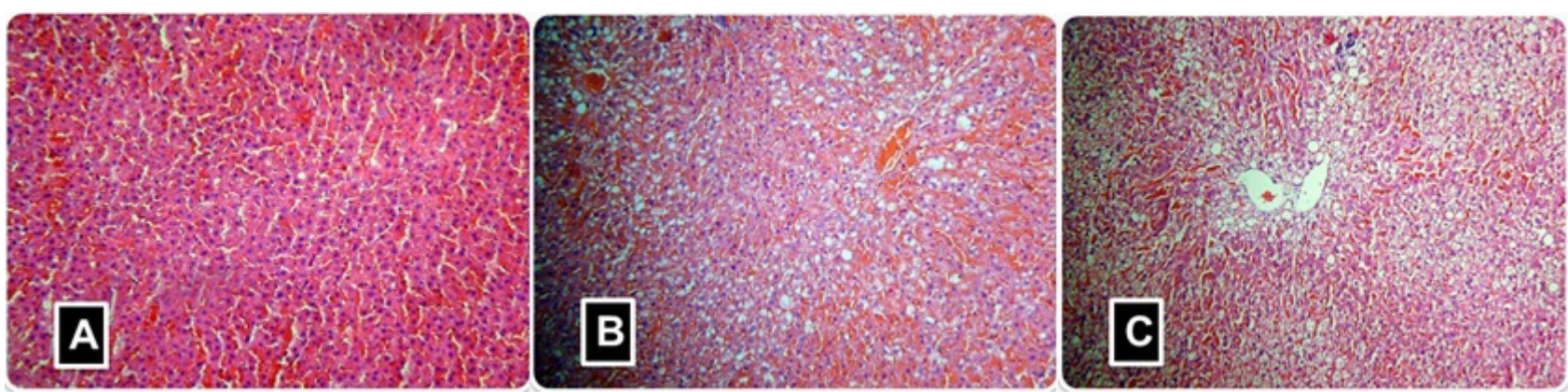

Figure 1. Histopathological evaluation: A) absence macrovesicular steatosis (H-E; 100x); B) moderate macrovesicular steatosis (H-E; 100x); C) severe macrovesicular steatosis (H-E; 100x). 
Table 2. Weight gain of groups at baseline and by the end of the experiment.

\begin{tabular}{|c|c|c|c|c|}
\hline \multirow{2}{*}{ Groups } & Initial body weight $(\mathrm{g})$ & Final body weight $(\mathrm{g})$ & \multirow{2}{*}{$p$-valor } & \multirow{2}{*}{ Delta weight $(\mathrm{g})$} \\
\hline & mean \pm SD & mean \pm SD & & \\
\hline Baru Trained $(n=5)$ & $440.74 \pm 31.62$ & $472.84 \pm 49.52$ & $.043 *$ & $31.41 \pm 19.14^{\mathrm{AB}}$ \\
\hline Baru Sedentary $(n=5)$ & $414.80 \pm 30.72$ & $490.16 \pm 49.16$ & $.043^{*}$ & $65.52 \pm 16.79^{\mathrm{A}}$ \\
\hline Cafeteria Trained $(n=4)$ & $479.45 \pm 18.92$ & $509.65 \pm 31.41$ & .068 & $33.35 \pm 13.76^{\mathrm{AB}}$ \\
\hline Cafeteria Sedentary $(n=6)$ & $407.20 \pm 47.09$ & $462.93 \pm 62.81$ & $.028^{*}$ & $45.56 \pm 10.75^{\mathrm{A}}$ \\
\hline Control Trained $(n=4)$ & $420.22 \pm 28.52$ & $403.20 \pm 28.09$ & .068 & $-17.02 \pm 9.79^{\mathrm{B}}$ \\
\hline Control Sedentary $(n=4)$ & $384.02 \pm 20.54$ & $405.30 \pm 24.45$ & .465 & $21.28 \pm 29.14^{\mathrm{AB}}$ \\
\hline
\end{tabular}

*Mean values were significantly different from those of the initial and final experiment ( $p$-valor $<.05$; Wilkoxon Signed Ranks test); Means that do not share the same letters are statistically different $(\mathrm{A} \neq \mathrm{B}: p<.05$; Kruskal-Wallis test with post-hoc Dunn).

There was no statistical difference between the trained groups fed a high-fat diet and the trained control group, although this was the only group that presented negative delta weight (Table 2). Therefore, the proposed training protocol attenuated the body weight gain promoted by hypercaloric diet.

The positive diagnosis of NAFLD was less prevalent in the trained animals when compared to sedentary ones, irrespective of the ration offered. NAFLD was not identified in trained group fed a Baru diet (Table 3), as showed by histopathological evaluation of each condition (Figure 2).

Table 3. Classification of steatosis.

\begin{tabular}{lcc}
\hline \multirow{2}{*}{ Groups } & $\begin{array}{c}\text { Present } \\
\text { (moderate or severe) }\end{array}$ & Absent \\
\cline { 2 - 3 } & $n(\%)$ & $n(\%)$ \\
\hline Baru Trained & $0(0)$ & $5(100)$ \\
Baru Sedentary & $4(80)$ & $1(20)$ \\
Cafeteria Trained & $2(50)$ & $2(50)$ \\
Cafeteria Sedentary & $5(83.33)$ & $1(16.67)$ \\
Control Trained & $1(25)$ & $3(75)$ \\
Control Sedentary & $2(50)$ & $2(50)$ \\
\hline
\end{tabular}
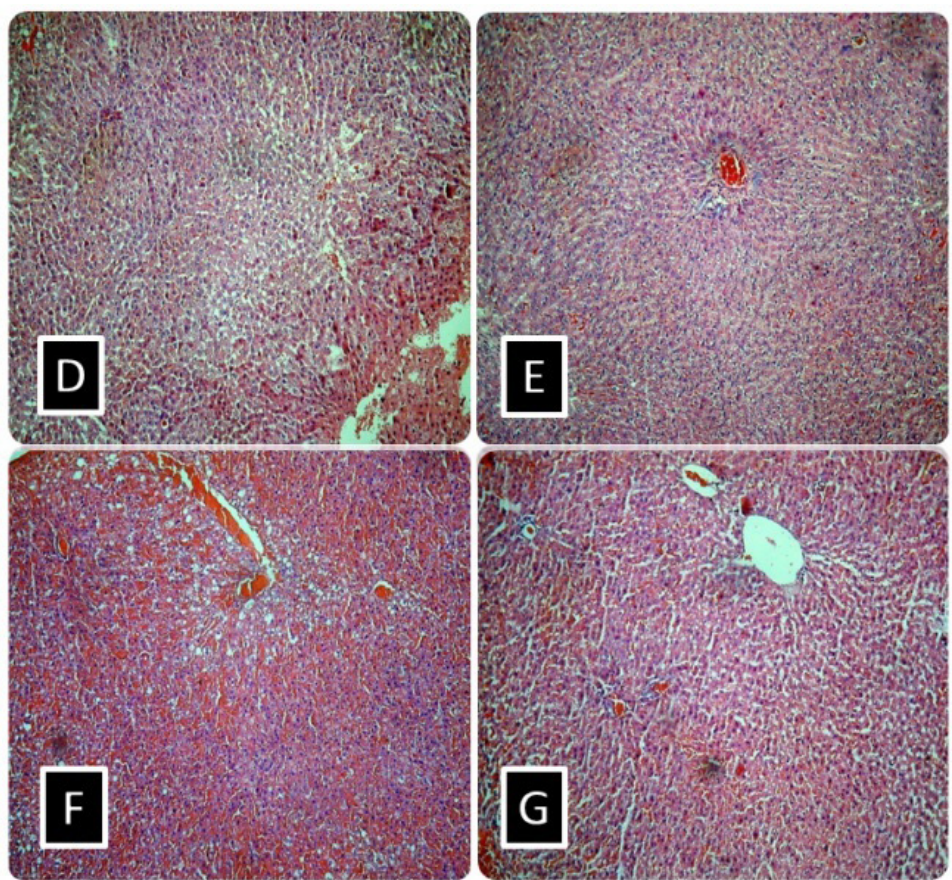

Figure 2. Histopathological evaluation of experimental groups (each condition) (H-E; 100x): D) Baru Sedentary (moderate macrovesicular steatosis); E) Baru Trained (absence macrovesicular steatosis); F) Cafeteria Sendentary (moderate macrovesicular steatosis); G) Cafeteria Trained (severe macrovesicular steatosis).

\section{Discussion}

In the present study, the administration of a high-fat diet resulted in body weight gain as well as occurrence of NAFLD, which was attenuated by swimming physical training at sub- threshold intensity. Inadequate food and low energy expenditure are the greatest contributory factors to the increase in obesity and metabolic disturbances all over the world (Popkin et al., 2012; Rector \& Thyfault, 2011). It has been reported that a high-fat administered to animal models developed obesity and 
fat liver accumulation (Burlamaqui et al., 2011; De Souza et al., 2005). Cafeteria diet is known to promote obesity, to increase adipose tissue and plasma levels of leptin, triglycerides and total cholesterol (Macedo et al., 2012). On the other hand, physical exercise represents a key element in the prevention of these negative alterations.

Studies have demonstrated that physical exercise diminished the expression of genic transcription factors involved in lipid synthesis and increased lipolytic enzyme expression in eutrophic obese rats (Cintra et al., 2012) fed high-fat diets ( $42 \% \mathrm{Kcal})$ for two weeks (Yasari et al., 2010) and improved the mitochondrial functionality in genetically hyperphagic rats (accepted model of metabolic syndrome) (Rector et al., 2008b). Furthermore, in other studies, physical exercise improved the blood lipid profile, reduced body mass and visceral adiposity (Estadella et al., 2004), improved the glucagon action and (Charbonneau, Couturier, Gauthier, \& Lavoie, 2005) insulin resistance condition (Marques, Motta, Torres, Aguila, \& Mandarim-de-Lacerda, 2010). These studies have proved the efficacy of physical training in the sense of avoiding the accumulation of fat in the liver via modulation of lipogenic and lipolytic enzymes, in addition to reducing metabolic complications resulting from a high-fat diet.

As far as studies involving physical training are concerned, there is a vast amount of information with respect to their effects on hepatic lipid metabolism at moderate or vigorous intensities, directly reflecting the recommendations to populations as regards physical activity for health promotion and maintenance. However, studies with animal models have observed positive effects on lipid metabolism as a consequence of voluntary physical exercise (without control of intensity) in running circuits, with attenuation of NAFLD (Rector et al., 2008b). In a study conducted by our research group, we observed that light intensity reduced the hepatic triglyceride content, in both Baru and Cafeteria Groups, although they did not present a reduction in body weight; however, only the Cafeteria Group significantly reduced visceral and inguinal adiposity (Ravagnani et al., 2012).

In the present study, we demonstrated that the proposed physical training protocol was capable of reducing the prevalence of NAFLD, even without calorie readjustment and/or reduction in the animals' body weight, since all groups fed with high-fat diet showed an increase in body weight; on the other hand, only the trained groups had lower prevalence of hepatic steatosis. Although studies that have observed the efficacy in the treatment of NAFLD in human beings observed the concomitant reduction of 3 to $10 \%$ in body weight (Johnson et al., 2012), there is evidence that physical training is able to reduce the hepatic lipid levels by mechanisms independent of weight variation (George et al., 2009), once calorie readjustment after induced obesity did not appear to present benefits in the metabolic parameters, associated with insulin resistance, when physical training was not included (Estadella et al., 2004).

It is known that regular physical exercise is the most efficient way to treat NAFLD (Bürgi \& Dufour, 2012), nevertheless, the metabolic adaptations may be different, depending on the type of training performed and/or which diet is offered (Horowitz, 2003). Physical exercise plays a primordial role in the treatment of obesity and in behavioral therapies, however, its practice combined with adequate diet presents additional benefits, and is associated with the prevention of diabetes type 2 and cardiovascular diseases (Avenell et al., 2004). Importantly, obesity predisposes the subject to cardiovascular events and joint lesions during a session of physical training, therefore, the light intensity may be the safest choice for the treatment of these diseases.

The Cafeteria and Baru diets contained an appropriate lipid profile (high unsaturated fat content), thus, being high-calorie diets. Therefore, due to the effect of calorie and lipid overload, irrespective of the degree of saturation of their molecules (Anderson \& Jürgen Borlak, 2008), high prevalence of NAFLD was expected. However, this effect was attenuated by the physical training with sub-threshold load. It is important to emphasize that there is difference in the composition of lipids ( $4.24 \%$ lower in Baru diet) and calories $(5.04 \mathrm{Kcal} / 100 \mathrm{~g}$ higher in Cafeteria diet) between the experimental diets; nevertheless, this reduction in the lipids supply occurred only after the diet-induced obesity model. Therefore, the harm to health was expected (i.e., consumption of unsaturated fat), as aforementioned (Burlamaqui et al., 2011; De Souza et al., 2005; Macedo et al., 2012). Even with this reduction, this diet can be considered as both high-fat and high-calorie (Reeves, Nielsen, \& Fahey, 1993).

It is important to point out that the trained Baru group did not present positive diagnosis of NAFLD. This suggest that the Baru oil, which is rich in unsaturated fatty acids, $(78.5 \%$ of the total lipids, $44.5 \%$ of oleic acid and $31.7 \%$ of linoleic acid) and $\alpha$-tocopherol $(5 \mathrm{mg} / 100 \mathrm{~g})$, may provide benefits in metabolic diseases treatment due to its known antioxidant function (Takemoto, Garbelotti, Tavares, \& Aued-Pimentel, 2001). Furthermore, the baru nut has a low ratio of Omega6/Omega3, thereby contributing to cardiovascular diseases risks reduction; it is relevant to say that the peanuts used in the Cafeteria diet has a ten-fold higher ratio than the Baru nut (Freitas \& Naves, 2010). Diets with a high Omega6/Omega3 ratio, and/or poor in Omega3, trigger factors that contribute to the process of various diseases, including NAFLD (El-Badry, Graf, \& Clavien, 2007; Simopoulos, 2000). Diets rich in Omega 3 improve the control of triglyceride concentrations in the liver, the hepatic oxidation of lipids and diminish the lipogenic capacity (Neschen et al., 2002; Valenzuela \& Videla, 2011). But, it is not sufficient to prevent NAFLD if the diet used is high-fat in experiments with sedentary animals (Burlamaqui et al., 2011).

Over the last 100 years, alterations in the eating pattern, such as a reduction in the antioxidant vitamins intake, Omega 3 fatty acids and increase in the total fats and Omega6 fatty acids intakes (Simopoulos, 2000), in parallel to the increase in sedentarism, probably as a result of technological advancement (Hamilton, Hamilton, \& Zderic, 2007), have led to diverse risks to human health. The inclusion of foods with alleged functionality in the diet is a trend that has aroused the curiosity of the pharmaceutical industry. Particularly in the developing countries, the therapeutic use of medicinal plants and native fruits is common, in spite of being little known from the scientific point of view (Ikeda, 2010).

Baru has a nutritional composition that is more favorable to health in comparison with products extensively used industrially, such as the Brazil nut, cashew nut, peanut, almonds and 
other edible seeds (Freitas \& Naves, 2010). The Baru extract combined with physical training presented promising results in the reduction of NAFLD prevalence; however, further studies are necessary to verify its benefits to health and its potential use in the food and pharmaceutical industries.

The present study had a limitation that should be considered, such as the number of animals $(n=4)$ used to determine the liver steatosis in Cafeteria Trained group. Moreover, we recognize that a greater number of the animals could be of value in this sense.

In conclusion, the intake of a high-fat diet resulted in high prevalence of NAFLD in rats. This outcome was attenuated by physical training at sub-threshold intensity, even without calorie reduction and/or reduction in body weight. In addition, we point out that the physical training protocol combined with the ether extract of Baru potentiated these effects.

\section{References}

Anderson, N., \& Jürgen Borlak. (2008). Molecular Mechanisms and Therapeutic Targets in Steatosis and Steatohepatitis. Pharmacological Reviews, 60, 311-357. doi:10.1124/pr.108.00001.311

Avenell, A., Broom, J., Brown, T. J., Poobalan, A., Aucott, L., Stearns, S. C., ... Grant, A. M. (2004). Systematic review of long-term effects and economic consequences of treatments for obesity. Health Technology Assessment, 8, 1-182.

Bugianesi, E., McCullough, A. J., \& Marchesini, G. (2005). Insulin resistance: a metabolic pathway to chronic liver disease. Hepatology, 42, 987-1000. doi:10.1002/hep.20920

Bürgi A.C., \& Dufour J.F. (2012). [Treatment of nonalcoholic steatohepatitis]. La Revue Du Praticien, 62, 1425-1427. Retrieved from http://www.ncbi.nlm.nih.gov/pubmed/23424927

Burlamaqui, I. M. B., Dornelas, C. A., Jr, J. T. V., Mesquita, F. J. C., Veras, L. B., \& Rodrigues, L. V. (2011). Hepatic and biochemical repercussions of a polyunsaturated fat-rich hypercaloric and hyperlipidic diet in 'wistar rats. Arquivos de Gastroenterologia, 48, 153-158.

Charbonneau, A., Couturier, K., Gauthier, M. S., \& Lavoie, J. M. (2005). Evidence of hepatic glucagon resistance associated with hepatic steatosis: reversal effect of training. International Journal of Sports Medicine, 26, 432-441. doi:10.1055/s-2004-821225

Cintra, D. E., Ropelle, E. R., Vitto, M. F., Luciano, T. F., Souza, D. R., Engelmann, J., ... De Souza, C. T. (2012). Reversion of hepatic steatosis by exercise training in obese mice: the role of sterol regulatory element-binding protein-1c. Life Sciences, 91, 395-401. doi:10.1016/j.lfs.2012.08.002

Cotrim, H. P., Parise, E. R., Oliveira, C. P. M. S., Leite, N., Martinelli, A., Galizzi, J., ... Oliveira, F. (2011). Nonalcoholic fatty liver disease in Brazil. Clinical and histological profile. Annals of Hepatology, 10, 33-37. Retrieved from http://www.ncbi.nlm.nih. gov/pubmed/21301007

De Souza, C. T., Araújo, E. P., Prada, P. O., Saad, M. J. A., Boschero, A. C., \& Velloso, L. A. (2005). Short-term inhibition of peroxisome proliferator-activated receptor-gamma coactivator-1alpha expression reverses diet-induced diabetes mellitus and hepatic steatosis in mice. Diabetologia, 48, 1860-1871. doi:10.1007/ s00125-005-1866-4

El-Badry, A. M., Graf, R., \& Clavien, P.-A. (2007). Omega 3 - Omega 6: What is right for the liver? Journal of Hepatology, 47, 718-725. doi:10.1016/j.jhep.2007.08.005

Estadella, D., Oyama, L. M., Dâmaso, A. R., Ribeiro, E. B., \& Nasci- mento, C. M. O. Do. (2004). Effect of palatable hyperlipidic diet on lipid metabolism of sedentary and exercised rats. Nutrition, 20 , 218-224. doi:10.1016/j.nut.2003.10.008

Freitas, J. B., \& Naves, M. M. V. (2010). Composição química de nozes e sementes comestíveis e sua relação com a. Revista de Nutrição, 23, 269-279.

George, A. St., Bauman, A., Johnston, A., Farrell, G., Chey, T., \& George, J. (2009). Independent effects of physical activity in patients with nonalcoholic fatty liver disease. Hepatology, 50, 68-76. doi:10.1002/hep. 22940

Hamilton, M., Hamilton, D., \& Zderic, T. (2007). Role of low energy expenditure and sitting in obesity, metabolic syndrome, type 2 diabetes, and cardiovascular disease. Diabetes, 56(November), 2655-2667. doi:10.2337/db07-0882.CVD

Harri, M., \& Kuusela, P. (1986). Is swimming exercise or cold exposure for rats? Acta Physiologica Scandinavica, 126, 189-197. doi:10.1111/j.1748-1716.1986.tb07805.x

Horowitz, J. F. (2003). Fatty acid mobilization from adipose tissue during exercise. Trends in Endocrinology \& Metabolism, 14, 386-392. doi:10.1016/S1043-2760(03)00143-7

Ikeda, A. A. (2010). Considerações sobre tendências e oportunidades dos alimentos funcionais. Revista P\&D Em Engenharia de Produção, 8, 40-56.

Johnson, N. a, Keating, S. E., \& George, J. (2012). Exercise and the liver: implications for therapy in fatty liver disorders. Seminars in Liver Disease, 32, 65-79. doi:10.1055/s-0032-1306427

Jou, J., Choi, S., \& Diehl, A. (2008). Mechanisms of disease progression in nonalcoholic fatty liver disease. Seminars in Liver Disease, 28 , 370-379. doi:10.1055/s-0028-1091981.

Krawczyk, M., Bonfrate, L., \& Portincasa, P. (2010). Nonalcoholic fatty liver disease. Best Practice \& Research. Clinical Gastroenterology, 24, 695-708. doi:10.1016/j.bpg.2010.08.005

Lewis, J. R., \& Mohanty, S. R. (2010). Nonalcoholic fatty liver disease: a review and update. Digestive Diseases and Sciences, 55, 560-578. doi:10.1007/s10620-009-1081-0

Macedo, I. C., Medeiros, L. F., Oliveira, C., Oliveira, C. M., Rozisky, J. R., Scarabelot, V. L., ... Torres, I. L. S. (2012). Cafeteria diet-induced obesity plus chronic stress alter serum leptin levels. Peptides, 38, 189-196. doi:10.1016/j.peptides.2012.08.007

Marques, C. M. M., Motta, V. F., Torres, T. S., Aguila, M. B., \& Mandarim-de-Lacerda, C. A. (2010). Beneficial effects of exercise training (treadmill) on insulin resistance and nonalcoholic fatty liver disease in high-fat fed C57BL/6 mice. Brazilian Journal of Medical and Biological Research, 43, 467-475.

Neschen, S., Moore, I., Regittnig, W., Yu, C. L., Wang, Y., Pypaert, M., ... Shulman, G. I. (2002). Contrasting effects of fish oil and safflower oil on hepatic peroxisomal and tissue lipid content. American Journal of Physiology. Endocrinology and Metabolism, 282, E395-401. doi:10.1152/ajpendo.00414.2001

Popkin, B. M., Adair, L. S., \& Ng, S. W. (2012). The global nutrition transition: the pandemic of obesity developing countries. Nutrition Reviews, 70, 3-21. doi:10.1111/j.1753-4887.2011.00456.x.NOW

Ravagnani, F. C. de P., Ravagnani, C. de F. C., Neto, J. A. B., Voltarelli, F. A., Zavala, A. A. Z., Habitante, C. A., \& Inouye, C. M. (2012). Effects of high fat diets with baru extract and chocolate on adipocyte area of rats subjected to physical exercise. Revista Brasileira de Medicina Do Esporte, 18, 190-194.

Rector, R. S., \& Thyfault, J. P. (2011). Does physical inactivity cause nonalcoholic fatty liver disease? Journal Applied Physiology, 111, 1828-1835. doi:10.1152/japplphysiol.00384.2011.

Rector, R. S., Thyfault, J. P., Laye, M. J., Morris, R. T., Borengasser, S. J., Uptergrove, G. M., ... Ibdah, J. a. (2008a). Cessation of daily exercise dramatically alters precursors of hepatic steatosis in 
Otsuka Long-Evans Tokushima Fatty (OLETF) rats. The Journal of Physiology, 586, 4241-4249. doi:10.1113/jphysiol.2008.156745

Rector, R. S., Thyfault, J. P., Morris, R. T., Laye, M. J., Borengasser, S. J., Booth, F. W., \& Ibdah, J. a. (2008b). Daily exercise increases hepatic fatty acid oxidation and prevents steatosis in Otsuka Long-Evans Tokushima Fatty rats. American Journal of Physiology Gastrointest and Liver Physiology, 294, G619-626. doi:10.1152/ ajpgi.00428.2007

Reeves, P. G., Nielsen, F. H., \& Fahey, G. C. (1993). AIN-93 purified diets for laboratory rodents: final report of the American Institute of Nutrition ad hoc writing committee on the reformulation of the AIN-76A rodent diet. The Journal of Nutrition, 123, 1939-1951. Retrieved from http://www.ncbi.nlm.nih.gov/pubmed/8229312

Simopoulos, A. . (2000). Human requirement for N-3 polyunsaturated fatty acids. Poultry Science, 79, 961-970.

Takemoto, E., Garbelotti, I. A., Tavares, M., \& Aued-Pimentel, S. (2001). Chemical composition of seeds and oil of baru (Dipteryx alata Vog) native from Pirenópolis, State of Goiás, Brazil. Revista Instituto Adolfo Lutz, 60, 113-117.

Valenzuela, R., \& Videla, L. A. (2011). The importance of the longchain polyunsaturated fatty acid n-6/n-3 ratio in development of non-alcoholic fatty liver associated with obesity. Food \& Function, 2, 644-648. doi:10.1039/c1 fo10133a

Voltarelli, F. a, Gobatto, C. a, \& de Mello, M. a R. (2002). Determination of anaerobic threshold in rats using the lactate minimum test. Brazilian Journal of Medical and Biological Research, 35, 1389-1394.

World Healt Organization. Joint WHO/FAO Expert Consulation. (2002). Diet, nutrition and the prevention of chronic diseases. Geneva: WHO.

Yasari, S., Prud'homme, D., Wang, D., Jankowski, M., Levy, E., Gutkowska, J., \& Lavoie, J.-M. (2010). Exercise training decreases hepatic SCD-1 gene expression and protein content in rats. Molecular and Cellular Biochemistry, 335, 291-299. doi:10.1007/ s11010-009-0279-y

\section{Authors' note}

Valdemar Guedes da Silva, Fabrício Cesar de Paula Ravagnani, Allan da Mata Godois, Fabrício Azevedo Voltarelli, and Christianne de Faria Coelho-Ravagnani are affilaited with the Physical Aptitude, Metabolism and Health Center (NAFIMES/UFMT), Cuiabá, MT, Brazil

Odashiro Maçanori and Celso Massaschi Inouye are affiliated with the Federal University of Mato Grosso do Sul, Campo Grande, MS, Brazil

\section{Acknowledgments}

CAPES, Coordenação de Aperfeiçoamento de Pessoal de Nível Superior; FUNDECT, Fundação de Apoio ao Desenvolvimento do Ensino, Ciência e Tecnologia do Estado de Mato Grosso do Sul; FAPEMAT - Fundação de Amparo à Pesquisa do Estado de Mato Grosso.

\section{Corresponding author}

Valdemar Guedes da Silva

Address: Rua 80, Quadra 26, Casa 25, bairro CPA 3, setor 1, Cuiabá 78.058-488, MT, Brazil

Phone.: 55-65-8153-3394

E-mail: valdemar_em37@hotmail.com

Manuscript submitted on March 9, 2014

Manuscript accepted on October 24, 2014

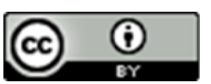

Motriz. The Journal of Physical Education. UNESP. Rio Claro, SP, Brazil - eISSN: 1980-6574 - under a license Creative Commons - Version 3.0 